\title{
IMPACT OF RAINFALL TEMPORAL VARIABILITY ON RAINFED MAJOR FOOD CROPS AND AGRONOMIC PRACTICES IN THE NORTH WESTERN COASTAL ZONE OF EGYPT
}

\author{
El-Sadek, Ashraf N. and Emad M.M. Salem* \\ Department of Plant Production, Ecology and Dry land Agriculture \\ Division, Desert Research Center, Cairo, Egypt \\ *E-mail: emadmms@yahoo.com
}

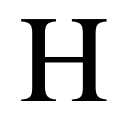

igh variability in rainfall amount and occurrence are the main constraints for crop production in rainfed arid and semi-arid areas. Precipitation data analysis focusing on rainfall amount, distribution and dry spells is of a great importance to mitigate the drought impact on crop production. In this study, we used the very, easily accessed daily data from the National Center for Environmental Prediction; Climate Forecast System Reanalysis (NCEP/CFSR) for a period of 35 years (1979-2014) over the North Western Coast (NWCZ) of Egypt at four locations: Ras El Hekma, Matrouh, El Neguilla and Barrani. The data of total annual rainfall, maximum daily data and the number of rainy days based on $0.1,5,10,15 \mathrm{~mm}$ of rain, long and short dry spells and the start of the rainy season were presented. The analysis of the dry spells showed that there are at least 6 to 7 dry spells of 10 days or longer each year with a probability exceeding $20 \%$ in all the locations studied. Data also showed that Barrani has the highest total annual precipitation and maximum daily precipitation of $182 \mathrm{~mm}$ and $45 \mathrm{~mm}$, respectively. A number of the rainy days of the four examined thresholds of $0.1,5,10$ and $15 \mathrm{~mm}$ were higher in Barrani as compared to the other three locations. It is quite clear that the productivity of wheat, barley and other crops in the NWCZ is highly dependent on the amount and distribution of rainfall as well as the dry spells distribution. Therefore, available water management practices such as supplemental irrigation and water harvesting techniques should be implemented to reduce the potential drought developed for dry spells and to improve the productivity of the cultivated crops.

Keywords: precipitation data, time series analysis, NCEP/CFSR, dry spell, NWCZ, Egypt 
Precipitation is the primary factor affecting crop production in rainfed areas, particularly in the Mediterranean arid and semi-arid regions. Not only the rainfall amount affects the crop growth and yield, but also the temporal and spatial distribution of this rain. Some other variables also affect the crop production include the length of the rainy season, dry spell (consecutive days without rain) duration and the rainfall intensity. Calculating these variables requires also determining the beginning and the end of the rainy season, which is one of the main interests of this paper.

Studying the rainy season duration and characteristics for agricultural purposes has been previously investigated. This includes; estimating the growing season's length, the emergence and the establishment of the rangeland species (Elberse and Breman, 1990 and Kutiel et al., 2000). Determining the optimum planting dates for rainfed crops (Bannayan et al., 2013); they used the adjusted crop evapotranspiration and Dry Days since Last Rain to determine the optimum planting date for rainfed wheat in Iran. Dry spell analysis using rainfall data is helpful in describing the agroclimatic conditions (Barron et al., 2003), who indicated that the dry spell occurrence accompanied with a low soil water holding capacity negatively impact the crop yield. Rainfall variability-crop relation was also highlighted (Bewket, 2009 in Ethiopia; Yamusa et al., 2015 in Nigeria and Poudel and Shawk, 2016 in Nepal).

The reanalysis products represent a valuable source of a continuous precipitation record, in particular in areas with a limited number of ground stations (El-Sadek et al., 2011). One of such available reanalysis products is The National Centers for Environmental Prediction/Climate Forecast System Reanalysis (NCEP/CFSR; Saha et al., 2010 and 2014). Some researchers (e.g. Yuan et al., 2011) have attempted to use these data for hydrological prediction, as inputs for hydrological models (Fuka et al., 2013; Dile and Srinivasan, 2014; Alemayehu et al., 2015 and Roth and Lemann, 2016) and to derive crop growth models (Shin et al., 2010).

The North West Coastal Zone of Egypt (NWCZ) is run over a distance of $500 \mathrm{~km}$ from Alexandria in the east to the Libyan border in the west. Rainfall is the main limiting factor for the agricultural activity in the area, it has a typical Mediterranean climate with an annual precipitation amount of $140 \mathrm{~mm}$. Farmers production strategy primary manages risks and reduce losses by diversifying cropping systems. In the rainy seasons, farmers make crucial decisions in what, where and when to plant. Good and relatively deep soil in the Wadis is allocated to horticulture (olive and fig), which also is characterized by its closeness to the sea and the highest amount of fallen rain. Area $20-50 \mathrm{~km}$ inland from the sea consists of land depressions and flat topography are left for barley with a small area allocated for wheat, however low quality soils are left for pastures (El-Naggar et al., 1988 and Ali et al., 2007). Barley as the major crop grown in the area is mainly used to feed livestock on grain, straw, and stubble. The cultivated

Egyptian J. Desert Res., 66, No. 1, 169-186 (2016) 
area reaches 126000 ha, a good proportion of farmers used to grow wheat; however a very small area is allocated for other crops such as faba bean and lentil.

The objectives of this research are: 1) to analyze the daily annual rainfall over the rainfed areas in the NWCZ of Egypt, 2) to identify the relation between rainfall and crop production and 3) It also suggests adaptation techniques to mitigate the impact of rainfall limitation and variability.

\section{MATERIALS AND METHODS}

\section{Study Area}

The domain of the study area is located in the North Western Costal Zone of Egypt (NWCZ), which extends from Ras El Hekma in the east to Barrani in the west. Fig. (1) and table (1) show the location of the study area.

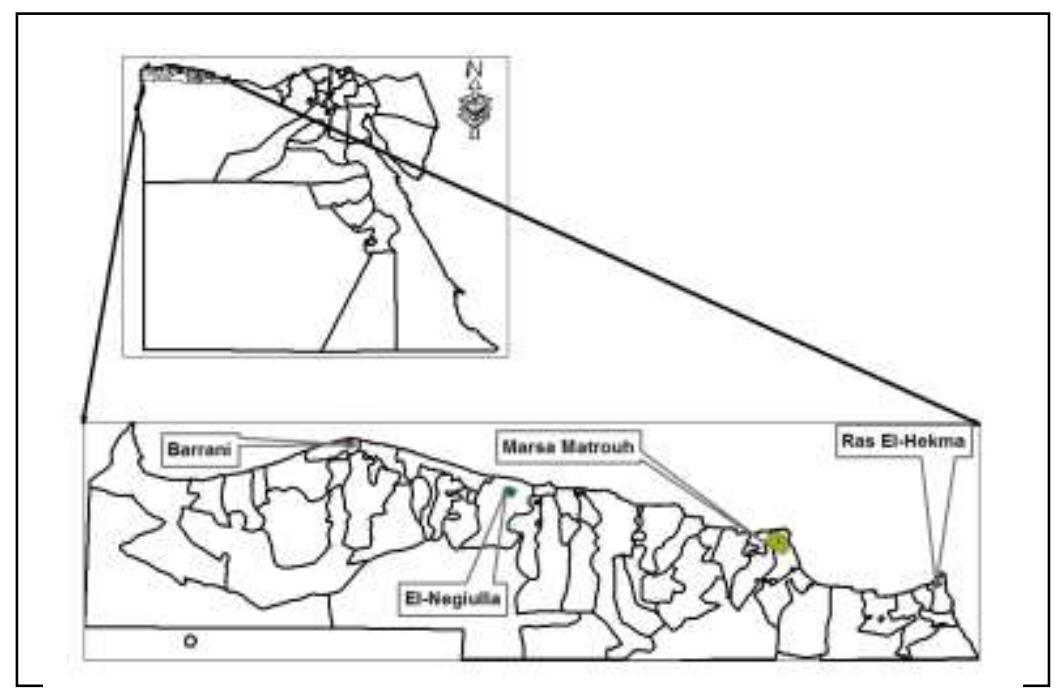

Fig. (1). Location of the study area.

Table (1). List of pseudo climate stations over the NWCZ of Egypt.

\begin{tabular}{ccccc}
\hline Station no. & Station name & Latitude & Longitude & Available data period \\
\hline 311278 & Ras El Hekma & 27.81 & 31.06 & $01 / 01 / 1979-$ \\
& (RH) & & & $31 / 07 / 2014$ \\
314272 & Matrouh (MT) & 27.19 & 31.38 & $01 / 01 / 1979-$ \\
& & & & $31 / 07 / 2014$ \\
314266 & El Neguilla & 26.56 & 31.38 & $01 / 01 / 1979-$ \\
& (EN) & & \multirow{2}{*}{31.69} & $01 / 07 / 2014$ \\
317259 & Barrani (BR) & 25.93 & & $31 / 07 / 2014$ \\
& & & & \\
\hline
\end{tabular}




\section{Data Description}

Data used for this investigation are daily precipitation from the National Center for Environmental Prediction; Climate Forecast System Reanalysis NCEP/CFSR. The CFSR is a fully atmosphere-ocean-land surface-sea ice system to provide the best estimate of the state of these coupled domains in the period (Saha et al., 2010). The CFSR global atmosphere resolution is $\sim 38 \mathrm{~km}$ (T382) with 64 levels. The global ocean is $0.25^{\circ}$ at the equator, extending to a global $0.5^{\circ}$ beyond the tropics, with 40 levels. The data are available for the period from 1979-2009 and was extended to 2014. The data set is available for direct download free of charge from this website: http://rda.ucar.edu/pub/cfsr.html.

\section{Data Analysis}

The rainfall data were analyzed using the Instat v3.37 @ statistical package (University of Reading, 2008) and Addinsoft's XLSTAT software (2014) to determine the variability of annual rainfall. Instat software was developed by the Statistical Service Center of the University of Reading in the United Kingdom. It is public domain software that performs the statistical analysis as well as a range of climate analyses. It calculates water balance from rainfall and evaporation, the start of the rains, degree-days, wind direction frequencies, spell lengths, potential evapotranspiration according to Penman and the crop performance index according to methodology used by the Food and Agriculture Organization of the United Nations (FAO). The software was used for the agro climatic analysis by Sivakumar et al. (1993).

All the rainfall parameters were calculated based on the hydrological year starting from 1 October to 30 September, which is more useful for the agro-meteorological studies for winter rainfed crops. A day was considered as a rainy day when rainfall was $\geq 0.1 \mathrm{~mm}$. Rains fall during a single season, lasting from October to March and sometimes, it is extended up to April, Characterized by high inter annual variability and non-uniform distribution within seasons.

The first step in the analysis was to extract the required data and the total annual precipitation was calculated for each year over the study period. The data were then subjected to basic statistical analysis and trend analysis to determine their variability in the area. The basic statistical analysis involved determining the mean, the median (measures of tendencies), standard deviation (a measure of dispersion), Skewness (a measure of degree of symmetry) and finally the Kurtosis (a measure of peakedness of the data).

\section{Precipitation Trend Analysis}

The precipitation annual trend was analyzed using the MannKendall monotonic trend test with a $90 \%$ confidence interval. In the test process Ho means there is no trend in the population, and Ha means that

Egyptian J. Desert Res., 66, No. 1, 169-186 (2016) 
there is a trend in the population. Ho is rejected if $p \leq 1$. The trend was quantified using the Sen's slope method developed by Sen (1968) using the equation

$Q_{i}=\frac{x_{j-} x_{k}}{j-k}$ For $\mathrm{i}=1,2,3, \ldots \ldots \ldots, \mathrm{N}$

Where $x_{j}$ and $x_{k}$ are data values at time $j$ and $k(j>k)$, respectively.

\section{Daily Rainfall Threshold (DRT)}

Defining the daily rainfall threshold or what is known a rainy day is a critical decision. This definition will affect other parameters such as the length of the rainy season, duration, number and yield of rainy-spells as well as the duration of the dry spells (Reiser and Kutiel, 2009). In our study, we used 4 daily rainfall threshold of $0.1,5,10,15 \mathrm{~mm}$ as described in Aviad et al. (2009), except that our maximum threshold is $15 \mathrm{~mm}$ and they used $25 \mathrm{~mm}$ as a maximum threshold, the number of the rainy days was calculated based on these 4 thresholds.

\section{The Beginning of the Rainy Season}

The date of the beginning of the rainy season was determined for each year and at each location, in our case, the rainy season starts on the first day which the rainfall equal to or exceed a threshold of $10 \mathrm{~mm}$. This threshold was chosen, because we think that it can trigger the emergence of the wheat and barley grains (Gutterman, 1993).

\section{Length of the Dry Spells}

The dry spell is defined as successive days with zero rain, two types of dry spells were identified; i.e., dry spells, $\geq 10$ days, and dry spells, $<10$ days.

\section{RESULTS AND DISCUSSION}

Local Bedouins have defined nine major rain storms (Nawat) during the rainy season. which are: 1) Tout within the period from 1/9-20/10, it is an early rain but usually farmers don't rely on this storm for barley cultivation as the weather is still hot, and it may be followed by a prolonged dry spell which may lead to crop failure (false start; Liakatas, 1997 and Laux at al., 2008), 2) Al thorayia from 20/10-15/11,3) Al Esafer from 15/1130/11, 4) Al Gozaa'a from 1/12-25/12, 5) Al Mirzim from 25/12-10/1, 6) Al Nejaimat from 10/1-10/2, 7) Al forar from 10/2-1/3, 8) Amsher (March) from $1 / 3-1 / 4$ and that event is crucial as it occurs during the grain filling periods of the grown barley and wheat, and finally 8) April from 1/4-1/5, this rain event is rarely occuring. 


\section{Basic Statistics}

The results of the basic statistical analysis for the parameters considered for this work are presented in table (2). Also, fig, (2 and 3) show the frequencies, mean, maximum and minimum of the annual rainfall at the four locations. The data showed that the highest mean annual rainfall was recorded at Barrani (182 mm) and the lowest was at Ras El Hekma (98 mm), while it was 145 and $129 \mathrm{~mm}$ for Matrouh and El Neguilla, respectively. Some other parameters were created using these data and are shown in table (2), overall the studied locations; the maximum total annual rainfall was recorded in Barrani in 1991 season $(289.9 \mathrm{~mm})$, while the lowest was 37.34 $\mathrm{mm}$ that recorded at El Neguilla in the 2010 season. Accordingly, it is quite clear that yearly rainfall is highly variable and irregular.

Table (2). Statistical summary of the annual rainfall series (1979-2014).

\begin{tabular}{ccccc}
\hline Parameters & Matrouh & $\begin{array}{c}\text { Ras El } \\
\text { Hekma }\end{array}$ & $\begin{array}{c}\text { El } \\
\text { Neguilla }\end{array}$ & Barrani \\
\hline Minimum & 63.190 & 39.290 & 37.340 & 40.880 \\
Maximum & 261.200 & 170.400 & 218.500 & 289.800 \\
1 st Quartile & 123.200 & 74.693 & 99.453 & 148.900 \\
Median & 144.300 & 94.020 & 126.050 & 173.300 \\
3rd Quartile & 162.125 & 119.300 & 162.150 & 219.050 \\
Mean & 144.976 & 98.381 & 128.805 & 181.937 \\
Variance (n-1) & 1654.972 & 1421.322 & 1805.857 & 3355.387 \\
Standard deviation (n-1) & 40.681 & 37.700 & 42.495 & 57.926 \\
Skewness & 0.397 & 0.461 & -0.040 & -0.041 \\
Kurtosis & 0.813 & -0.642 & -0.728 & -0.174 \\
Standard error of the mean & 6.977 & 6.466 & 7.288 & 9.934 \\
Mean absolute deviation & 29.163 & 29.830 & 35.019 & 45.638 \\
\hline
\end{tabular}

The skewness as the measure of symmetry; showed that the data obtained from Matrouh and Ras El Hekma are skewed to the right. However the data of El Neguilla and Barrani are slightly skewed to the left. Kurtosis refers to the peakedness or flatness relative to the normal distribution. Kurtosis data showed that rainfall data of Matrouh location has a positive kurtosis which indicates a peaked distribution; however the other three locations have negative Kurtosis indicating a flat distribution.

\section{Precipitation Trend}

According to the Sen's slope tests presented in table (3), the total annual precipitation decreased by $1.28,1.53,1.67$ and $2.09 \mathrm{~mm}$ for Ras El Hekma, Matrouh, El Neguilla and Barrani, respectively. table (3) also presents the Mann-Kendall test and null hypothesis test at $90 \%$ confidence

Egyptian J. Desert Res., 66, No. 1, 169-186 (2016) 
level $(\alpha=0.1)$ for the annual rainfall over the four locations. As illustrated in table (3) results show a negative trend in all the four locations, indicating that the annual rainfall decreases with time. The results are statistically significant with $\mathrm{P}$ values $\leq 0.1$, which results in rejecting the null hypothesis, indicating that there is a trend in the data for all the locations.

Table (3). Sen's slope for the annual precipitation at the four locations.

\begin{tabular}{cccccc}
\hline Station & $\begin{array}{c}\text { Sen's } \\
\text { slope } \\
(\mathbf{m m})\end{array}$ & $\begin{array}{c}\text { Kendall's } \\
\text { tau }\end{array}$ & $\begin{array}{c}\text { p- } \\
\text { value }\end{array}$ & $\begin{array}{c}\text { Alpha } \\
\text { value }\end{array}$ & Significance \\
\hline Ras El Hekma & -1.28 & -0.216 & 0.075 & 0.1 & Yes \\
Matrouh & -1.53 & -0.273 & 0.024 & 0.1 & Yes \\
El Neguilla & -1.67 & -0.251 & 0.037 & 0.1 & Yes \\
Barrani & -2.09 & -0.255 & 0.035 & 0.1 & Yes \\
\hline
\end{tabular}

\section{Maximum Daily Rainfall}

Maximum daily rainfall is very important for flash hazards, the highest maximum rainfall of $45 \mathrm{~mm}$ was recorded in Barrani in 1998 and the next two highest maximum daily rainfall were $42 \mathrm{~mm}$ in Matrouh in 1986 and $40 \mathrm{~mm}$ in Ras El Hekma in 1985 (Table 4). However, for El Neguilla the highest maximum rainfall was $36 \mathrm{~mm}$ in 1980. In Barrani location the rainfall of $42 \mathrm{~mm}$ had a relative frequency of only 0.029 and observed only once, while the highest relative frequency of 0.324 , which has been recorded 11 times was for the maximum daily values between 18.4-23 $\mathrm{mm}$. The lowest maximum daily rainfall of $5 \mathrm{~mm}$ was recorded in Ras El Hekma in 1984, $8 \mathrm{~mm}$ in 2013 for Matrouh, $6 \mathrm{~mm}$ in 2001 at El Neguilla and finally 7 $\mathrm{mm}$ at Barrani in 2010 (Table 4).

\section{Number of Rainy Days}

The number of rainy days of equal to or larger than $0.1,5,10,15$ $\mathrm{mm}$ was calculated for the 4 locations (Tables 4 and 5). In general, Barrani has the highest number of rainy days for all the thresholds with an average number of $50.29,10.12,3.17$ and 1.53 days for the daily rainfall threshold of 0.1,5, 10 and $15 \mathrm{~mm}$, respectively. On the other hand, Ras El Hekma has the lowest number of rainy days of $34.47,4.44,1.26$ and 0.29 for the 4 thresholds, respectively. There was a high correlation between the total annual rainfall and the number of the rainy days, for instance, the highest number of rainy days in 1992 seasons corresponds to the high rainfall years in all locations. Similar results were obtained by Kwarteng et al. (2009).

\section{Length of the Dry Spells}

Dry weather adversely affects the farmers activities. During the rainy season, long dry spells have severely impacted on plant growth and development, many techniques can be used to mitigate the adverse impact of 
the drought under rainfed conditions. Defining the probability of occurrence and the length of these dry spells is of a great important to adapt suitable management techniques. Table (6) shows the number of long dry spells (10 days or more without rain) and the number of short dry spells (less than 10 days) with no rain. Data show that Ras El Hekma and Barrani tend to have a lower number of long dry spells with an average of 6.6 and 6.7 times/season as compared to Matrouh and El Neguilla with 7.7 and 7.6 times/season, respectively.

The highest number of long dry spells was 10 in Matrouh,El Neguilla, Barrani, while it was 11 days in Ras El Hekma. Year of 1986 was the highest year for the recorded number of long dry spells. For the short dry spells, Barrani recorded the highest number of short dry spells over a year (16.62) with a maximum of 26 dry spells in the 1991 season, this year also recorded the highest number of dry spells for El Neguilla (27 times/year) and the second highest for Ras El Hekma 21 times/year. However, for Matrouh the year of 1995 had the highest number of short dry spells (23). In Matrouh the probability of having 8 to 9 of dry spells of 10 days or longer was $29.4 \%$ and this probability exceeds $20 \%$ for having $7-8$, 8-9 and 6-7 dry spell of 10 days or longer in Ras El Hekma, El Neguilla and Barrani, respectively.

Long dry spells could affect the crop water uptake during the different crop development stages, which result in a reduction in the total crop yield up to $75 \%$ (Barron et al., 2003). Accurate information about dry spells for a specific location is essential for selecting the proper crop and the suitable cultivar. A prior knowledge about the dry spells would help the farmers for better managing his field by implementing water conservation techniques, supplemental irrigation, adding fertilization and determining the optimum time of planting dates.

\section{Start Date of Rainfall}

Many studies have used different threshold values to determine the beginning of the rainy season, for example: Aviad et al. (2004) used 58 different thresholds in which some were from 0.1-80 $\mathrm{mm}$ with an interval of $2.5 \mathrm{~mm}$ and from 80 to $200 \mathrm{~mm}$ with an interval of $5 \mathrm{~mm}$. A rain amount of $10 \mathrm{~mm}$ is considered as a full irrigation event, we considered the first date of $10 \mathrm{~mm}$ of rain is the planting date for wheat and barley in the area. Data in table (6) show that the date of start of rainfall is highly variable; however, most of the time there is an event of $10 \mathrm{~mm}$ of rain in Barrani in October. The growing season generally starts in late October till mid of November and ends in April, according to the length of the rainy season. As it was expected, seasons that didn't have any records of $10 \mathrm{~mm}$ of rain, the barley and wheat failed to produce any yield and in this case farmers use the barley field as an open grazing area. Generally increasing the aridity shortens the length of the growing season (Aviad et al., 2004). It can be said that, it is not

Egyptian J. Desert Res., 66, No. 1, 169-186 (2016) 
only the total rainfall that affects the crop yield, but also the distribution of that rainfall over the season (Adiku et al., 1997).

Table (4). Total annual rainfall, maximum daily rainfall and number of rainy days at the locations for the hydrological years (1980-2013).

\begin{tabular}{|c|c|c|c|c|c|c|c|c|c|c|c|c|}
\hline \multirow[t]{2}{*}{$\begin{array}{c}\text { Parameter } \\
\text { year }\end{array}$} & \multicolumn{4}{|c|}{$\begin{array}{l}\text { Annual rainfall } \\
(\mathrm{mm})\end{array}$} & \multicolumn{4}{|c|}{$\begin{array}{c}\text { Maximum daily } \\
\text { rainfall } \\
(\mathbf{m m})\end{array}$} & \multicolumn{4}{|c|}{$\begin{array}{c}\text { Daily rainfall } \\
\text { threshold } \\
(0.1 \mathrm{~mm}) \\
\end{array}$} \\
\hline & MT & RH & EN & $\mathbf{B R}$ & MT & RH & $\mathbf{E N}$ & BR & MT & RH & $\mathbf{E N}$ & BR \\
\hline 1980 & 169.10 & 88.51 & 128.60 & 141.60 & 19 & 11 & 36 & 32 & 47 & 32 & 41 & 38 \\
\hline 1981 & 78.01 & 39.29 & 66.56 & 127.10 & 10 & 8 & 8 & 19 & 34 & 20 & 35 & 43 \\
\hline 1982 & 130.70 & 101.90 & 161.10 & 219.10 & 12 & 8 & 22 & 29 & 36 & 41 & 41 & 58 \\
\hline 1983 & 198.40 & 169.10 & 175.90 & 218.50 & 19 & 32 & 14 & 17 & 58 & 48 & 53 & 65 \\
\hline 1984 & 74.57 & 63.74 & 94.52 & 160.90 & 16 & 5 & 9 & 21 & 27 & 31 & 34 & 37 \\
\hline 1985 & 148.10 & 154.00 & 179.80 & 236.50 & 10 & 40 & 32 & 28 & 45 & 28 & 38 & 44 \\
\hline 1986 & 188.40 & 100.90 & 151.50 & 173.80 & 42 & 12 & 16 & 15 & 41 & 36 & 47 & 54 \\
\hline 1987 & 147.40 & 84.73 & 106.10 & 202.00 & 13 & 10 & 13 & 18 & 50 & 24 & 43 & 50 \\
\hline 1988 & 193.70 & 141.90 & 182.60 & 233.20 & 15 & 15 & 15 & 24 & 54 & 44 & 54 & 60 \\
\hline 1989 & 188.10 & 131.50 & 151.00 & 187.00 & 17 & 14 & 18 & 21 & 65 & 45 & 52 & 56 \\
\hline 1990 & 158.80 & 74.50 & 117.50 & 153.50 & 13 & 12 & 10 & 20 & 50 & 33 & 43 & 48 \\
\hline 1991 & 132.40 & 167.30 & 185.10 & 289.80 & 9 & 9 & 12 & 16 & 47 & 56 & 68 & 75 \\
\hline 1992 & 261.20 & 170.40 & 218.50 & 281.70 & 12 & 14 & 14 & 19 & 70 & 61 & 68 & 82 \\
\hline 1993 & 138.10 & 111.90 & 152.00 & 171.70 & 15 & 14 & 17 & 22 & 52 & 44 & 45 & 51 \\
\hline 1994 & 163.20 & 165.30 & 180.00 & 261.80 & 29 & 13 & 14 & 17 & 42 & 52 & 60 & 62 \\
\hline 1995 & 216.70 & 79.84 & 108.80 & 173.40 & 16 & 10 & 7 & 18 & 65 & 34 & 48 & 51 \\
\hline 1996 & 156.10 & 97.60 & 126.10 & 218.90 & 18 & 13 & 16 & 19 & 48 & 34 & 42 & 52 \\
\hline 1997 & 136.30 & 90.44 & 162.50 & 252.50 & 16 & 12 & 18 & 23 & 44 & 34 & 48 & 63 \\
\hline 1998 & 167.30 & 118.70 & 178.10 & 287.10 & 15 & 18 & 26 & 45 & 43 & 33 & 43 & 59 \\
\hline 1999 & 113.20 & 49.20 & 74.85 & 85.99 & 18 & 9 & 20 & 28 & 28 & 15 & 17 & 24 \\
\hline 2000 & 120.70 & 119.50 & 162.60 & 227.90 & 11 & 11 & 15 & 22 & 43 & 46 & 47 & 57 \\
\hline 2001 & 137.20 & 53.36 & 80.63 & 137.90 & 23 & 6 & 6 & 20 & 38 & 26 & 38 & 39 \\
\hline 2002 & 147.50 & 89.10 & 123.40 & 183.20 & 9 & 9 & 10 & 16 & 53 & 34 & 44 & 61 \\
\hline 2003 & 158.90 & 102.90 & 106.20 & 160.40 & 17 & 14 & 14 & 12 & 51 & 33 & 37 & 50 \\
\hline 2004 & 144.20 & 75.27 & 80.08 & 116.70 & 16 & 11 & 13 & 14 & 40 & 31 & 37 & 41 \\
\hline 2005 & 106.70 & 54.98 & 104.80 & 173.20 & 10 & 7 & 9 & 21 & 35 & 26 & 37 & 48 \\
\hline 2006 & 143.30 & 101.60 & 123.90 & 168.60 & 19 & 17 & 15 & 17 & 39 & 35 & 42 & 53 \\
\hline 2007 & 152.50 & 76.75 & 126.00 & 151.00 & 13 & 9 & 20 & 21 & 55 & 30 & 38 & 43 \\
\hline 2008 & 116.60 & 124.60 & 126.60 & 166.20 & 20 & 20 & 24 & 24 & 33 & 32 & 37 & 46 \\
\hline 2009 & 92.13 & 54.56 & 71.22 & 99.70 & 16 & 6 & 8 & 17 & 28 & 23 & 24 & 33 \\
\hline 2010 & 63.19 & 41.84 & 37.34 & 40.88 & 10 & 10 & 9 & 7 & 20 & 16 & 17 & 21 \\
\hline 2011 & 144.40 & 99.70 & 157.90 & 205.70 & 14 & 16 & 32 & 35 & 42 & 34 & 38 & 50 \\
\hline 2012 & 136.90 & 70.36 & 79.90 & 148.20 & 22 & 6 & 8 & 10 & 45 & 38 & 37 & 55 \\
\hline 2013 & 105.20 & 79.67 & 97.67 & 130.20 & 8 & 17 & 13 & 9 & 39 & 23 & 31 & 41 \\
\hline
\end{tabular}

Whereas: MT is Matrouh location, RH is Ras El Hekma location,EN is El

Neguillalocation and BR is Barranilocation. 
Table (5). Number of the rainy days based on different rainfall thresholds for the hydrological years (1980-2013).

\begin{tabular}{|c|c|c|c|c|c|c|c|c|c|c|c|c|}
\hline \multirow[t]{2}{*}{$\begin{array}{c}\text { Parameter } \\
\text { year }\end{array}$} & \multicolumn{4}{|c|}{$\begin{array}{c}\text { Daily rainfall } \\
\text { threshold } \\
(5 \mathrm{~mm})\end{array}$} & \multicolumn{4}{|c|}{$\begin{array}{l}\text { Daily rainfall } \\
\text { threshold } \\
(10 \mathrm{~mm})\end{array}$} & \multicolumn{4}{|c|}{$\begin{array}{c}\text { Daily rainfall } \\
\text { threshold } \\
(15 \mathrm{~mm})\end{array}$} \\
\hline & MT & RH & EN & BR & MT & RH & EN & BR & MT & RH & EN & BR \\
\hline 1980 & 10 & 5 & 4 & 6 & 3 & 1 & 1 & 2 & 1 & 0 & 1 & 1 \\
\hline 1981 & 2 & 1 & 2 & 5 & 0 & 0 & 0 & 2 & 0 & 0 & 0 & 1 \\
\hline 1982 & 8 & 5 & 7 & 9 & 3 & 0 & 5 & 6 & 0 & 0 & 2 & 3 \\
\hline 1983 & 9 & 7 & 10 & 15 & 5 & 4 & 4 & 3 & 1 & 2 & 0 & 1 \\
\hline 1984 & 3 & 3 & 7 & 10 & 1 & 0 & 0 & 5 & 1 & 0 & 0 & 2 \\
\hline 1985 & 10 & 7 & 10 & 12 & 1 & 3 & 4 & 7 & 0 & 2 & 2 & 5 \\
\hline 1986 & 9 & 4 & 7 & 11 & 4 & 1 & 3 & 3 & 3 & 0 & 1 & 1 \\
\hline 1987 & 8 & 3 & 5 & 10 & 1 & 1 & 1 & 5 & 0 & 0 & 0 & 2 \\
\hline 1988 & 11 & 6 & 12 & 13 & 6 & 3 & 3 & 3 & 1 & 1 & 0 & 2 \\
\hline 1989 & 8 & 6 & 7 & 10 & 2 & 3 & 2 & 3 & 1 & 0 & 1 & 1 \\
\hline 1990 & 10 & 3 & 5 & 9 & 2 & 1 & 1 & 2 & 0 & 0 & 0 & 2 \\
\hline 1991 & 8 & 10 & 11 & 18 & 0 & 0 & 1 & 6 & 0 & 0 & 0 & 1 \\
\hline 1992 & 19 & 8 & 10 & 14 & 2 & 2 & 5 & 5 & 0 & 0 & 0 & 2 \\
\hline 1993 & 5 & 3 & 7 & 9 & 1 & 2 & 4 & 3 & 1 & 0 & 2 & 1 \\
\hline 1994 & 10 & 9 & 11 & 17 & 3 & 2 & 2 & 4 & 2 & 0 & 0 & 2 \\
\hline 1995 & 15 & 3 & 6 & 9 & 3 & 1 & 0 & 3 & 1 & 0 & 0 & 2 \\
\hline 1996 & 7 & 5 & 8 & 14 & 2 & 3 & 1 & 6 & 1 & 0 & 1 & 3 \\
\hline 1997 & 5 & 1 & 11 & 17 & 1 & 1 & 2 & 4 & 1 & 0 & 1 & 2 \\
\hline 1998 & 10 & 6 & 10 & 15 & 3 & 3 & 3 & 7 & 1 & 1 & 2 & 4 \\
\hline 1999 & 8 & 3 & 4 & 5 & 3 & 0 & 1 & 1 & 1 & 0 & 1 & 1 \\
\hline 2000 & 5 & 7 & 9 & 13 & 1 & 1 & 5 & 5 & 0 & 0 & 1 & 3 \\
\hline 2001 & 6 & 1 & 2 & 9 & 4 & 0 & 0 & 2 & 2 & 0 & 0 & 1 \\
\hline 2002 & 9 & 3 & 7 & 8 & 0 & 0 & 1 & 2 & 0 & 0 & 0 & 1 \\
\hline 2003 & 7 & 5 & 3 & 8 & 3 & 2 & 1 & 1 & 1 & 0 & 0 & 0 \\
\hline 2004 & 9 & 3 & 3 & 8 & 3 & 1 & 1 & 1 & 1 & 0 & 0 & 0 \\
\hline 2005 & 6 & 2 & 6 & 11 & 0 & 0 & 0 & 2 & 0 & 0 & 0 & 1 \\
\hline 2006 & 8 & 5 & 6 & 8 & 3 & 2 & 3 & 5 & 2 & 1 & 1 & 1 \\
\hline 2007 & 8 & 4 & 7 & 10 & 1 & 0 & 2 & 3 & 0 & 0 & 1 & 1 \\
\hline 2008 & 9 & 8 & 8 & 8 & 2 & 3 & 2 & 2 & 1 & 1 & 1 & 2 \\
\hline 2009 & 7 & 3 & 3 & 4 & 1 & 0 & 0 & 1 & 1 & 0 & 0 & 1 \\
\hline 2010 & 5 & 2 & 2 & 1 & 1 & 0 & 0 & 0 & 0 & 0 & 0 & 0 \\
\hline 2011 & 8 & 5 & 9 & 11 & 2 & 1 & 2 & 4 & 0 & 1 & 2 & 2 \\
\hline 2012 & 5 & 1 & 3 & 7 & 3 & 0 & 0 & 0 & 1 & 0 & 0 & 0 \\
\hline 2013 & 6 & 4 & 6 & 10 & 0 & 2 & 2 & 0 & 0 & 1 & 0 & 0 \\
\hline
\end{tabular}

Whereas: MT is Matrouh location, RH is Ras El Hekma location, EN is El Neguilla location and $\mathrm{BR}$ is Barrani location.

Egyptian J. Desert Res., 66, No. 1, 169-186 (2016) 
Table (6). Number of Long and short dry spells as well as the date of the first rain for the period from (1980-2013).

\begin{tabular}{|c|c|c|c|c|c|c|c|c|c|c|c|c|}
\hline \multirow[t]{2}{*}{$\begin{array}{l}\text { Parameter } \\
\text { year }\end{array}$} & \multicolumn{4}{|c|}{$\begin{array}{c}\text { Long dry spell } \\
\text { (equal/more than } 10 \\
\text { days) }\end{array}$} & \multicolumn{4}{|c|}{$\begin{array}{c}\text { Short dry spell } \\
\text { (less than } 10 \text { days) }\end{array}$} & \multicolumn{4}{|c|}{$\begin{array}{c}\text { Date of } \\
\text { the first } 10 \mathrm{~mm} \text { rain }\end{array}$} \\
\hline & MT & RH & EN & BR & MT & RH & EN & BR & MT & RH & EN & BR \\
\hline 1980 & 10 & 8 & 8 & 6 & 12 & 11 & 10 & 13 & $5 / 12$ & $22 / 11$ & $31 / 12$ & $31 / 12$ \\
\hline 1981 & 8 & 4 & 6 & 6 & 12 & 11 & 15 & 16 & - & - & - & $8 / 11$ \\
\hline 1982 & 6 & 10 & 9 & 5 & 14 & 15 & 14 & 22 & $13 / 2$ & - & $12 / 11$ & $11 / 11$ \\
\hline 1983 & 7 & 7 & 9 & 10 & 20 & 12 & 16 & 19 & $8 / 11$ & $13 / 10$ & $13 / 10$ & $3 / 10$ \\
\hline 1984 & 7 & 4 & 6 & 5 & 11 & 13 & 12 & 13 & $25 / 12$ & - & - & - \\
\hline 1985 & 6 & 9 & 8 & 8 & 15 & 6 & 10 & 12 & $17 / 1$ & - & $17 / 10$ & $13 / 10$ \\
\hline 1986 & 10 & 11 & 10 & 9 & 11 & 9 & 17 & 18 & $8 / 11$ & -- & $4 / 11$ & $4 / 11$ \\
\hline 1987 & 10 & 7 & 6 & 8 & 14 & 9 & 19 & 13 & $7 / 11$ & - & - & $5 / 10$ \\
\hline 1988 & 7 & 8 & 7 & 4 & 19 & 15 & 17 & 23 & $18 / 12$ & $3 / 10$ & $4 / 10$ & $12 / 10$ \\
\hline 1989 & 8 & 7 & 8 & 8 & 14 & 13 & 12 & 16 & 9/1 & $9 / 10$ & $9 / 10$ & $9 / 10$ \\
\hline 1990 & 9 & 6 & 10 & 8 & 13 & 11 & 12 & 14 & $18 / 10$ & $3 / 10$ & $3 / 10$ & $3 / 10$ \\
\hline 1991 & 9 & 7 & 6 & 7 & 15 & 21 & 27 & 26 & - & - & - & $11 / 10$ \\
\hline 19 & 7 & 6 & 7 & 7 & 20 & 22 & 20 & 22 & $1 / 1$ & $1 / 10$ & $19 / 10$ & $31 / 10$ \\
\hline 1993 & 5 & 5 & 6 & 7 & 18 & 18 & 16 & 13 & $20 / 12$ & - & $1 / 10$ & $7 / 10$ \\
\hline 1994 & 8 & 6 & 7 & 6 & 13 & 17 & 16 & 19 & $29 / 11$ & - & $7 / 10$ & $8 / 12$ \\
\hline 1995 & 6 & 6 & 8 & 9 & 23 & 14 & 16 & 18 & $10 / 10$ & - & - & $6 / 11$ \\
\hline 1996 & 6 & 7 & 7 & 6 & 19 & 14 & 20 & 19 & $5 / 1$ & $17 / 10$ & $17 / 10$ & $4 / 10$ \\
\hline 1997 & 9 & 9 & 8 & 6 & 12 & 10 & 18 & 21 & $19 / 1$ & $19 / 10$ & $20 / 11$ & $28 / 10$ \\
\hline 1998 & 7 & 4 & 6 & 6 & 15 & 17 & 21 & 24 & $16 / 3$ & $19 / 11$ & $10 / 11$ & $10 / 11$ \\
\hline 1999 & 8 & 8 & 8 & 5 & 8 & 4 & 4 & 11 & $9 / 12$ & - & $7 / 10$ & $7 / 10$ \\
\hline 2000 & 8 & 4 & 6 & 5 & 14 & 21 & 21 & 23 & $3 / 1$ & - & $3 / 10$ & $3 / 10$ \\
\hline 2001 & 7 & 9 & 9 & 6 & 14 & 7 & 13 & 16 & $24 / 10$ & - & - & - \\
\hline 2002 & 5 & 7 & 7 & 6 & 20 & 14 & 16 & 14 & - & - & $6 / 10$ & - \\
\hline 2003 & 8 & 7 & 7 & 6 & 19 & 13 & 14 & 20 & $16 / 10$ & $22 / 12$ & $22 / 12$ & $22 / 12$ \\
\hline 2004 & 7 & 6 & 5 & 6 & 11 & 10 & 17 & 15 & $10 / 11$ & $4 / 11$ & $4 / 11$ & $4 / 11$ \\
\hline 2005 & 7 & 5 & 7 & 5 & 11 & 8 & 12 & 18 & - & - & - & $8 / 10$ \\
\hline 2006 & 8 & 6 & 7 & 5 & 12 & 14 & 18 & 22 & $8 / 2$ & $14 / 11$ & $8 / 11$ & $10 / 10$ \\
\hline 2007 & 7 & 6 & 7 & 7 & 21 & 12 & 17 & 19 & - & - & $21 / 12$ & $13 / 10$ \\
\hline 2008 & 5 & 4 & 6 & 7 & 11 & 14 & 11 & 10 & $25 / 1$ & $10 / 10$ & $25 / 10$ & $25 / 10$ \\
\hline 2009 & 8 & 7 & 9 & 5 & 7 & 9 & 4 & 10 & $23 / 12$ & - & - & - \\
\hline 2010 & 9 & 8 & 8 & 9 & 4 & 3 & 4 & 4 & $9 / 12$ & - & - & - \\
\hline 2011 & 8 & 8 & 9 & 10 & 18 & 15 & 12 & 17 & $17 / 1$ & - & $17 / 10$ & $17 / 10$ \\
\hline 2012 & 7 & 5 & 8 & 8 & 16 & 18 & 16 & 18 & $13 / 11$ & - & - & - \\
\hline 2013 & 8 & 5 & 7 & 7 & 12 & 7 & 8 & 7 & - & $10 / 9$ & - & - \\
\hline
\end{tabular}

Whereas: MT is Matrouh location, RH is Ras El Hekma location, EN is El Neguilla location and BR is Barrani location. 


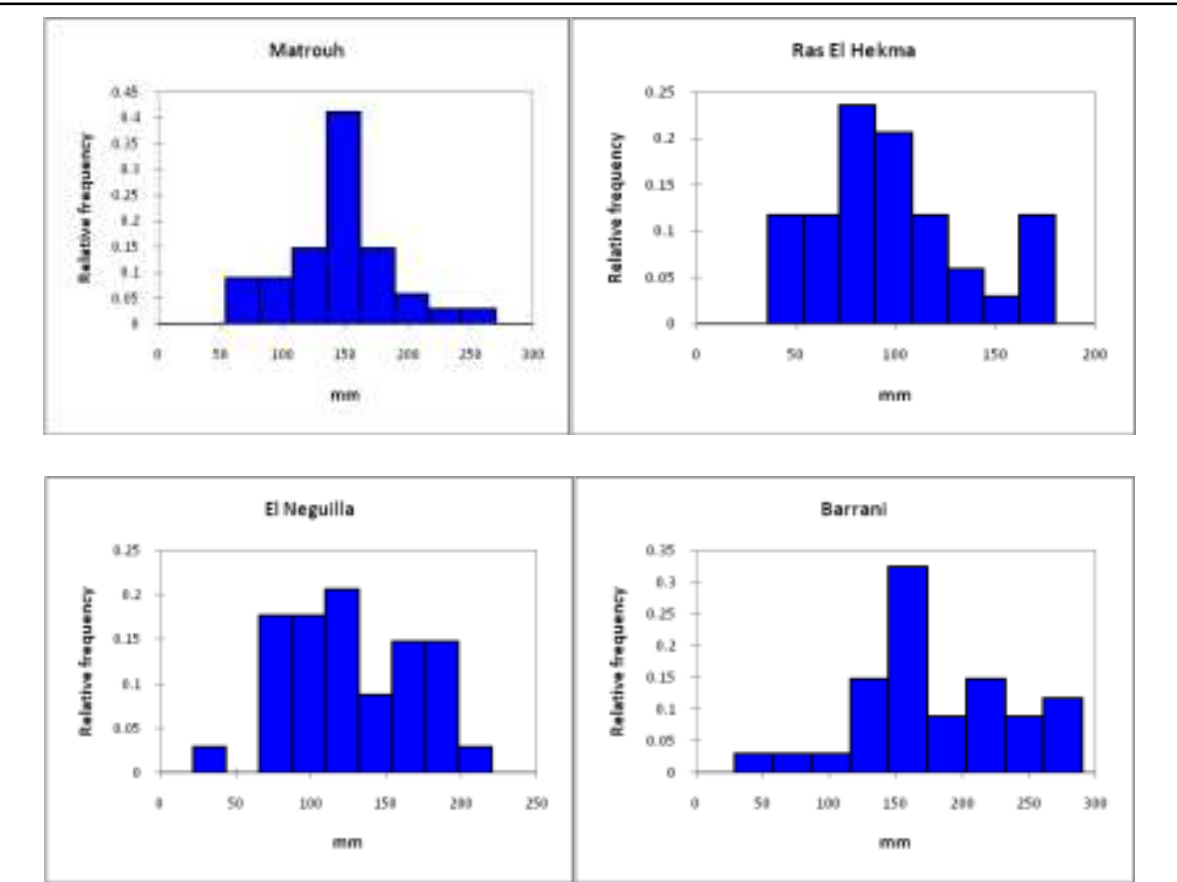

Fig. (2). Frequencies of the annual rainfall for the four locations.

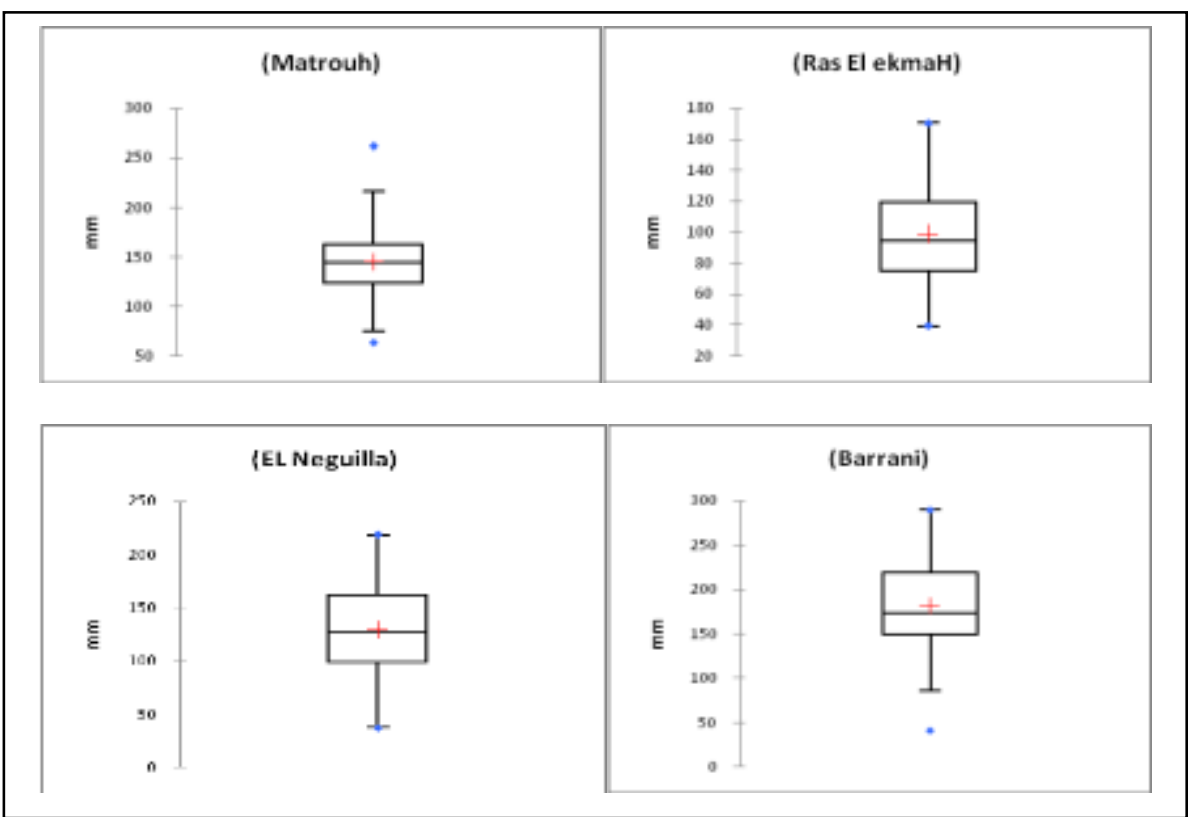

Fig. (3). Mean, maximum and minimum annual rainfall for Matrouh, Ras El Hekma,El Neguilla and Barrani over the period (1979-2013).

Egyptian J. Desert Res., 66, No. 1, 169-186 (2016) 


\section{Rainfall Data and Crop Production}

Rainfed agriculture in the area is highly relied on the amount and distribution of rainfall, barley and wheat yields fluctuate from year to year and from location to another. In El Neguilla, Kamel (2011) revealed that barley produced a grain yield of 0.585 t/ha during 2007/2008 growing season. According to the proposed climate change scenarios by Ouda et al. (2016), in 2030 the biological yield of barley and wheat will be decreased by 85 and $90 \%$, respectively which means that the two crops will fail to produce any grains as a result of rainfall decline.

Gomaa et al. (2013) recorded a barley yield of 184.9, 378.4, 373, 1 and $229.7 \mathrm{~kg} /$ fed in 2010/2011 season and 161.5, 156.8, 433.1 and 518.3 $\mathrm{kg} / \mathrm{fed}$ for Ras Elhekma, Matrouh,El Neguilla and Barrani for 2011/2012 season, respectively. As shown in table (6), it is clear that in the second season was having less number of dry spells of 10 days or longer as compared to the first season, which may explain the higher yield in the second season, although the total rain was higher according to the used data.

It is of interest to mention here that Gomaa (2007) reported that wheat grain yield achieved 148 and $163.6 \mathrm{~kg} / \mathrm{fed}$ while barley grains yield attained 183.5 and $223.8 \mathrm{~kg} / \mathrm{fed}$ for 2001/2002 and 2003/2004 growing seasons, respectively, under rainfed agriculture in Matrouh area. It may be inferred that the superiority of barley yield as compared with wheat yield refers to adaptability of barley to drought tolerance.

To sustain the rainfed agriculture in the area, many improved agricultural practices should be implemented to enhance the productivity of these crops. Example of these practices includes using supplemental irrigation during the critical growth stages and different water harvesting techniques (El-Sadek and Salem 2015 and 2016). Also, regarding the influence of the supplemental irrigation treatments on grain yield of wheat, Salem et al. (2003) found that supplemental irrigation by $60 \mathrm{~mm} / \mathrm{fed}$ gave the highest value of grain yield (588.23 and $563.07 \mathrm{~kg} / \mathrm{fed})$ compared with the rainfed only (281.04 and $201.28 \mathrm{~kg} / \mathrm{fed}$ ) for 2000/2001 and 2001/2002 growing seasons, respectively. Also, Attia (2006) indicated that rainfed water harvesting system secured the maximum wheat grain yield $(539.86$ and $578.6 \mathrm{~kg} / \mathrm{fed}$ ) as compared with rainfed only (185.05 and $202.75 \mathrm{~kg} / \mathrm{fed})$ for 1999/2000 and 2000/2001 growing seasons, respectively.

In view of the above mentioned results, it can be inferred the importance agronomic practices such as supplemental irrigation and water harvesting system to enhance the productivity of wheat and barley worthily and other crops in general under rainfed agriculture of North Western Coastal Zone of Egypt. 


\section{CONCLUSION}

Precipitation data for 4 locations along the North Western Coastal Zone of Egypt were analyzed and different parameters were calculated, i.e., maximum daily rainfall, the number of the rainy days for a daily rainfall threshold of $0.1,5,10$ and $15 \mathrm{~mm}$, long and short dry spells and the beginning of the rainy season. The used data were representing the period from 1979 until 2013 and the trend analysis revealed a slight decrease in the total annual precipitation at the four locations. Barrani location had the highest mean annual precipitation, maximum daily rainfall and the number of rainy days as compared to the other location. Such study is the first one focusing on analyzing the precipitation data in this coastal area, however, there are some limitations in the study. This study used only the precipitation data from only a single satellite based source due to the limited data availability of the ground stations. The study area seems to have less rainfall in the future, which will severely affect the crop production, so, intensive studies had to be done related to the climate change in this area for well-managed crop production.

\section{REFERENCES}

Addinsoft's XLSTAT 2014.3.07 (2014). Addinsoft. Copyright Addinsoft, 1995-2014. Available online: http://www.xlstat.com.

Adiku, S.G.K., P.W.A. Dayananda, C.W. Rose and G.N.N. Dowuona (1997). Analysis of the within-season rainfall characteristics and simulation of the daily rainfall in two savanna zones in Ghana. Journal of Agricultural and Forest Meteorology, 86: 51-62.

Alemayehu, T., A. Griensven and W. Bauwens (2015). Evaluating CFSR and WATCH data as input to SWAT for the estimation of the potential evapotranspiration in a data-scarce Eastern-African catchment. Journal of Hydrologic Engineering, 21 (3): 1-16.

Ali, A., T. Oweis, M. Rashid, S. El-Naggar and A. Abdul Aal (2007). Water harvesting options in the drylands at different spatial scales. Land Use and Water Resources Research, 7:1-13.

Attia, M.A.H. (2006). Cultivation of wheat under rainy conditions in West Matrouh. Ph.D. Thesis, Fac. of Agric., Ain Shams Univ., Egypt.

Aviad, Y., H. Kutiel and H. Lavee (2004). Analysis of beginning, end and length of the rainy season along a Mediterranean arid climate transect for geomorphic purposes. Journal of Arid Environments, 59: 189-204.

Aviad, Y., H. Kutiel and H. Lavee (2009). Variation of dry days since last rain (DDSLR) as a measure of drynessalong a Mediterranean-Arid transect. Journal of Arid Environments, 73: 658-665.

Egyptian J. Desert Res., 66, No. 1, 169-186 (2016) 
Bannayan, M., E. Rezaeib and G. Hoogenboom (2013). Determining optimum planting dates for rainfed wheat using the precipitation uncertainty model and adjusted crop evapotranspiration. Agricultural Water Management, 126: 56- 63.

Barron, J., J. Rockstrom, F. Gichuki and N. Hatibu (2003). Dry spell analysis and maize yields for two semi-arid locations in east Africa. Agricultural and Forest Meteorology, 117: 23-37.

Bewket, W. (2009). Rainfall variability and crop production in Ethiopia, Case study in the Amhara region. Proceedings of the $16^{\text {th }}$ International Conference of Ethiopian Studies (Ege, S., H. Aspen, B. Teferra and S. Bekele Eds.), Trondheim, p. 823-836.

Dile, Y.T. and R. Srinivasan (2014). Evaluation of CFSR climate data for hydrologic rrediction in data-scarce watersheds: An application in the Blue Nile River Basin. Journal of the American Water Resources Association, 1-16. DOI: 10.1111/jawr.12182

Elberse, W.T.H. and H. Breman (1990). Germination and establishment of Sahelian rangeland species. II. Water availability. Oecologia, 85: $32-$ 40.

El-Naggar, S., E.R. Perrier and M. Shykhoun (1988). Evaluation of farm resource management in the North West Coast of Egypt. Report No. ARS-SWRI/ICARDA-FRMP, presented in Alexandria/Marsa Matrouh, Egypt 4-7 April.

El-Sadek, A., M. Bleiweiss, M. Shukla, S. Guldan and A. Fernald (2011). Alternative climate data sources for distributed hydrologicalmodelling on a daily time step. Hydrolological Processes, 25: 1542-1557.

El-Sadek, A. and E. Salem (2015). Impact of ridge-furrow water harvesting system on faba bean (Vicia faba L.) production under rainfed conditions in Matrouh, Egypt. Annals of Agricultural Science, 60 (1): 61-66.

El-Sadek, A.N. and E.M.M. Salem (2016). Simulation of wheat yield using the RZWQM as affected by supplemental irrigation in the North Western Coast of Egypt. Egyptian Journal of Agronomy, 38 (2): 279-292.

Fuka, D.R., M.T. Walter, C.M. Alister, A.T. Degaetano, T.S. Steenhuis and Z.M. Easton (2013). Using the climate forecast system reanalysis as weather input data for watershed models. Hydrolological Processes, 28 (22): 5613-5623.

Gomaa, A.S.A. (2007). Agronomic and ecological studies on the productivity of wheat and barley in Umm Ashtan watershed area at North Western Coast of Egypt. Ph.D. Thesis, Fac. of Agric., Ain Shams Univ., Egypt.

Gomaa, M.A., F.I. Radwan, N.M.M. Moselhy and S.E. Abd-El-Kader (2013). Evaluation of different rainfed barley genotypes across

Egyptian J. Desert Res., 66, No. 1, 169-186 (2016) 
variable environments in Egypt Using GGE biplot analysis. Journal of Advances in Agricultural Researches, 18 (4): 796-809.

Gutterman, Y. (1993). In"Seed Germination in Desert Plants". SpringerVerlag Berlin Heidelberg, 253 pp.

Kamel, A. (2011). Cultural practices to combat degradation under rainfed areas in the Northern Coastal Plain in Egypt. International Journal of Water Resources and Arid Environments, 1 (5): 304-311.

Kutiel, P., H. Kutiel and H. Lavee (2000). Vegetation response to possible scenarios of rainfall variations along a Mediterranean-extreme arid climatic transect. Journal of Arid Environments, 44: 277-290.

Kwarteng, A.Y., A.S. Dorvlo and G.T.V. Kumar (2009). Analysis of a 27year rainfall data (1977-2003) in the Sultanate of Oman. International Journal of Climatology, 29: 605-617.

Laux, P., H. Kunstmann and A. Bardossy (2008). Predicting the regional onset of the rainy season in West Africa. International Journal of Climatology, 28: 329-342.

Liakatas, A. (1997). Growth and yield of rainfed wheat on seasonally dry Aegean islands. Theoretical and Applied Climatology, 58: 43-56.

Ouda, S., M. Ewise and T. Noreldin (2016). Projection of productivity of cultivated crops in rainfed areas in Egypt under climate change. Cogent food and Agriculture, 2: 1-13.

Poudel, S. and R. Shaw (2016). The relationships between climate variability and crop yield in a mountainous environment: A case study in Lampung District, Nepal. Climate, 4 (13). DOI: 10.3390/cli4010013.

Reiser, H. and Kutiel (2009). Rainfall uncertainty in the Mediterranean: definitions of the daily rainfall threshold (DRT) and the rainy season length (RSL). Theoretical and Applied Climatology, 97: 151-162.

Roth, V. and T. Lemann (2016). Comparing CFSR and conventional weather data for discharge and soil loss modeling with SWAT in small catchments in the Ethiopian Highlands. Hydrology and Earth System Science, 20: 921-934.

Saha,S., S. Moorthi, H. Pan, X. Wu, J. Wang, S. Nadiga et al. (2010). The NCEP climate forecast system reanalysis. American Meteorological Society, 91: 1015-1057.

Saha, S., S. Moorthi, H. Pan, X. Wu, J. Wang, S. Nadiga et al. (2014). The NCEP climate forecast system version 2. Journal of Climate, 27: 2185-2208.

Salem, E.M., M.A. Ashoub, M.O. Salem and M.F. Hamed (2003). Response of wheat to supplemental irrigation and fertilizer under North Western Coast of Egypt. Zagazig Journal of Agricultural Research, 30 (4): 1343-1363.

Sen, P. K. (1968). Estimates of the regression coefficient based on Kendall's Tau. Journal of the American Statistical Association, 63 (324):13791389.

Egyptian J. Desert Res., 66, No. 1, 169-186 (2016) 
Shin, D.W., G.A. Baigorria, Y.K. Lim, S. Cocke, T.E. LaRow, J.J. O'Brien and J.W. Jones (2010). Assessing maize and peanut yield simulations with various seasonal climate data in the Southeastern United States. Journal of Applied Meteorology and Climatology, 49: 592-603.

Sivakumar, M.V.K., A. Maidoukia and R. D. Stern (1993). Agroclimatology of West Africa: Niger. Information Bulletin No. 5. Patancheru, ICRISAT.

University of Reading (2008). Instat ${ }^{+\mathrm{TM}}$ an interactive statistical package. Statistical Services Centre, University of Reading, UK

Yamusa, A.M., I.U. Abubakar and A.M. Falaki (2015). Rainfall variability and crop production in the North-Western semi-arid zone of Nigeria. Journal of Soil Science and Environmental Management, 6 (5): 125131.

Yuan, X., E. F. Wood, L. Luo and M. Pan (2011). A first look at climate forecast system version 2 (CFSv2) for hydrological seasonal prediction. Geophysical Research Letters, 38, L13402: 1-7.

Received: 21/12/2016

Accepted: 20/2/2017 
تأثير التذبذب الزمني للأمطار على المحاصيل الغذائية الرئيسية المطرية

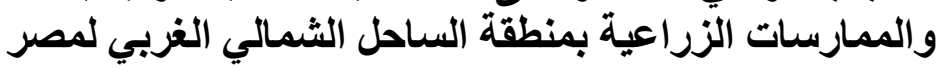

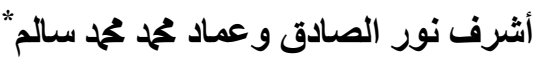

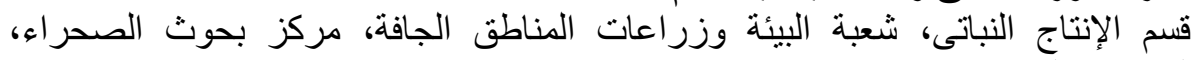

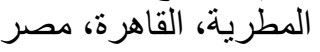

التباين الثديد في كمية هطول الأمطار وحدوث ذللك بصورة دائمة تمثل المعوقات

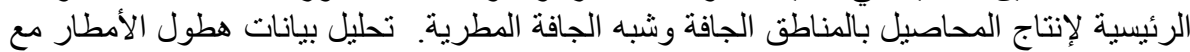

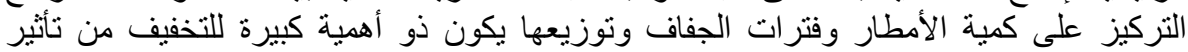

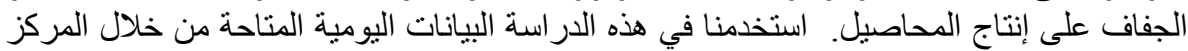

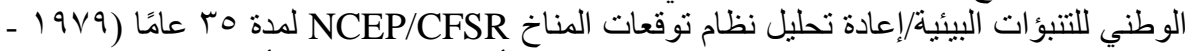

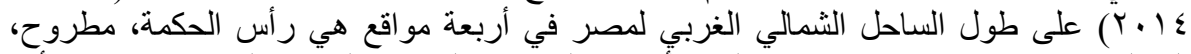

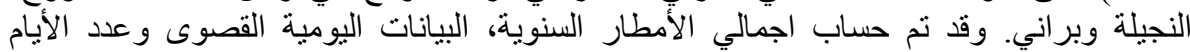

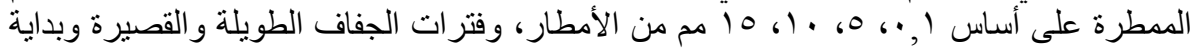

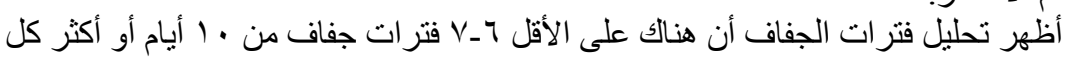
ونهاية موسم الأمطار.

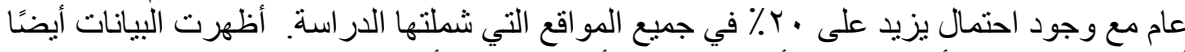

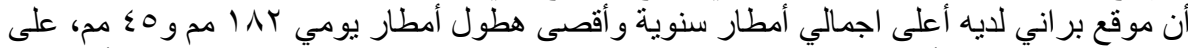

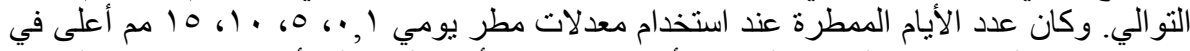

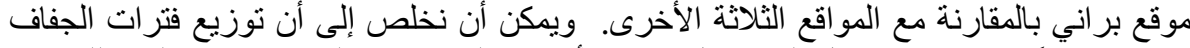

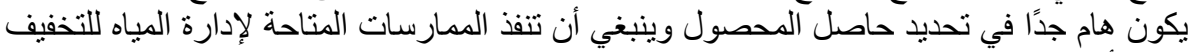
من التأثير السلبي لفترات الجفاف على انتاجية المحاصيل.

Egyptian J. Desert Res., 66, No. 1, 169-186 (2016) 